Web Jurnal:

http://ejournal.kemenperin.go.id/jli

\title{
Karakteristik pewarna alam gambir (Uncaria gambir Roxb) untuk produk pangan
}

\section{Characteristics of gambier (Uncaria gambir Roxb) as a natural dye for food products}

\author{
F Firdausni*, Gustri Yeni, F Failisnur, dan K Kamsina \\ Balai Riset dan Standardisasi Industri Padang \\ Jl. Raya LIK No.23 Ulu Gadut Padang, Indonesia \\ *e-mail: firdausni85@gmail.com
}

\begin{tabular}{|c|c|}
\hline INFO ARTIKEL & ABSTRAK \\
\hline Sejarah artikel: & Pewarna alami yang berpotensi untuk diekstrak diantaranya gambir (Uncaria gambir \\
\hline $\begin{array}{l}\text { Diterima: } \\
\text { 31 Oktober } 2019 \\
\text { Direvisi: } \\
\text { 16 Desember } 2019 \\
\text { Diterbitkan: } \\
\text { 30 desember } 2019\end{array}$ & $\begin{array}{l}\text { Roxb). Gambir mengandung senyawa tanin sebagai pewarna untuk pangan dan dapat } \\
\text { dijadikan alternatif pengganti pewarna sintetis yang aman untuk kesehatan. Penelitian ini } \\
\text { menggunakan Rancangan Acak Lengkap (RAL) dengan perlakuan metode ekstraksi dan } \\
\text { maserasi menggunakan pelarut (air, etanol } 25 \% \text {, etanol } 50 \% \text { ) dan pembangkit warna } \\
\text { (asam sitrat } 3 \% \text {, asam askorbat } 3 \% \text { dan kapur sirih } 5 \% \text { ) dengan } 3 \text { kali ulangan. } \\
\text { Penelitian bertujuan untuk melihat pengaruh pembangkit warna (fiksator) dalam } \\
\text { menghasilkan warna untuk pangan sebagai pengganti pewarna sintetis. Hasil penelitian } \\
\text { menunjukkan bahwa warna yang dihasilkan memiliki intensitas warna yang berbeda dari }\end{array}$ \\
\hline $\begin{array}{l}\text { Kata kunci: } \\
\text { gambir; } \\
\text { pewarna pangan; } \\
\text { intensitas warna; } \\
\text { pewarna alami }\end{array}$ & $\begin{array}{l}\text { kuning, kuning kemerahan dan merah kecoklatan. Pemakaian pelarut etanol } 25 \% \text { dan } \\
\text { pembangkit warna asam askorbat menghasilkan kecerahan warna L } 79,60 \text {, ketuaan warna } \\
\text { K/S } 1,15 \text { dengan arah warna kuning kemerahan }\left(a^{*} 6,5 \text { dan } b^{*} 23,99\right) \text {, aktivitas } \\
\text { antioksidan tertinggi dengan nilai IC } 50 \text { sebesar } 6,25 \mathrm{ppm} \text {, sedangkan kapur sirih } \\
\text { menghasilkan kecerahan warna L } 81,47 \text {, ketuaan warna K/S 4,09 dan arah warna merah } \\
\left.\text { tua (a* } 6,88 \text { dan } b^{*} 8,17\right) \text { mempunyai aktivitas antioksidan paling rendah yaitu } 7,84 \text { ppm. }\end{array}$ \\
\hline
\end{tabular}

Keywords:
gambier;
food dyes;
color intensity;
natural dyes

\begin{abstract}
Natural dyes that have a potential to be extracted include Gambier (Uncaria gambier. Roxb). Gambier contains tannin compounds as food coloring and can be used as an alternative substitute of synthetic dyes that are safe for health. The study used a completely randomized design (CRD) by extraction and maceration methods using solvents (water, ethanol 25\%, ethanol 50\%) and color generating (citric acid 3\%, ascorbic acid 3\%, and betel lime 5\% and 3 replications. The research aims to see the effect of color generator (fixator) in producing colors for food. The results showed that the colors produced had different color intensities from yellow, reddish yellow, and brownish red. The use of $25 \%$ ethanol solvent and ascorbic acid produced a color brightness $(L) 79.60$, color strength $(K / S) 1.15$ with redish yellow color and antioxidant activity $\left(I C_{50}\right)$ value 6.25 ppm, while by using betel lime produced a color brightness $(L)$ 81.47, color strength $(K / S) 4.09$ with dark red color and color direction $\left(a * 6.88\right.$ and $b^{*}$ 8.17). It has low antioxidant activity 7.84 ppm.
\end{abstract}

(C) 2019 Penulis. Dipublikasikan oleh Baristand Industri Padang. Akses terbuka dibawah lisensi CC BY-NC-SA

\section{Pendahuluan}

Warna pada makanan merupakan hal pertama yang menjadi faktor penentu konsumen dalam memilih satu produk di antara banyak produk lainnya. Warna juga merupakan salah satu indikator yang dipakai konsumen dalam menilai kualitas suatu produk. Pewarna pangan adalah zat aditif yang ditambahkan untuk meningkatkan warna makanan atau minuman. Pewarna pangan dicampurkan untuk memberi warna pada makanan, meningkatkan daya tarik visual pangan, merangsang indera penglihatan, menyeragamkan dan menstabilkan 
warna, dan menutupi atau mengatasi perubahan warna. Zat ini tersedia dalam berbagai bentuk seperti cairan, bubuk, gel, atau pasta.

Makanan yang mempunyai warna akan lebih disukai dibandingkan dengan yang tidak bewarna. Dalam menghasilkan warna yang menarik, produsen makanan sering menggunakan pewarna sintetis atau pewarna yang tidak diizinkan untuk makanan agar menghasilkan warna yang cerah, tahan lama dan menarik. Namun pewarna sintetis tidak aman dikonsumsi karena bersifat toksik, karsinogenik dan alergenik yang berdampak buruk terhadap kesehatan serta merusak lingkungan (Sulistyani, 2018).

Pewarna pangan selain dapat mempercantik penampilan makanan, juga yang terpenting adalah keamanannya terbebas dari racun dan zat kimia berbahaya, hal ini menjadi perhatian dalam pemilihan pelarut. Selain itu pewarna pangan diharapkan juga dapat memberikan pengaruh yang baik bagi kesehatan dari kandungan senyawa aktif yang dimilikinya (Suter, 2013).

Pewarna makanan alami sudah dikenal oleh masyarakat Indonesia sejak zaman dahulu, seperti daun suji, kunyit, kesumba, kulit manggis (Aji and Ferani, 2013). Bahan pewarna alami tersedia dalam jumlah yang berlimpah di alam, dapat diperbaharui dan berkelanjutan (Shahid et al., 2013). Dari beberapa tumbuhan dapat diekstrak warnanya mulai dari akar, batang, daun dan bunganya.

Pewarna alami terbuat dari tumbuhan, hewan, mineral, atau sumber alami lain. Menurut Peraturan Menteri Kesehatan Republik Indonesia No.033 Tahun 2012 tentang Bahan Tambahan Pangan, daftar pewarna alami yang diperbolehkan adalah kurkumin, riboflavin, karmin dan ekstrak cochineal, klorofil, karamel, karbon tanaman, beta-karoten, ekstrak anato, karotenoid, merah bit, antosianin, dan titanium dioksida.

Tren penggunaan pewarna alami saat ini selain dapat memberikan warna, juga untuk memberikan sifat fungsional tertentu. Kandungan senyawa fungsional dalam beberapa tanaman dapat memberikan efek antioksidan, antimikroba, antimutasi, dan aktivitas antineoplastik (Li et al., 2013). Rendahnya jumlah penggunaan pewarna alami terkait dengan kurang praktisnya dalam pemakaian dan belum banyaknya pewarna alami yang dijual di pasaran sehingga produsen makanan harus membuat sendiri pewarna makanan yang dibutuhkan tersebut.

Penelitian penggunaan Gambir sebagai pewarna tekstil telah banyak dilakukan seperti pemanfaatan Gambir untuk kain sutera (Failisnur and Sofyan, 2014), pemanfaatan limbah Gambir untuk kain batik (Failisnur et al., 2017) . Warna yang dihasilkan berasal dari tanin dan katekin Gambir. Komponen Gambir tanin dalam bentuk asam kateku tannat sebagai senyawa flavonoid yang merupakan zat warna.

Seiring meningkatnya kesadaran manusia terhadap kesehatan dan lingkungan, sehingga menginginkan ketersediaan produk pangan dengan pewarna alami. Konsep back to nature yang akhir-akhir ini dikembangkan merupakan solusi terhadap masalah pangan tersebut yang didukung dengan ketersediaan sumber daya lokal.
Beberapa penelitian telah dilakukan diantaranya pemanfaatan tumbuhan sebagai pewarna alami pangan dari kulit buah naga (Handayani. P A and Rahmawati Asri, 2012), tanaman putri malu (Mimosa pudica) (Marnoto et al., 2012), cabe (Piperetrofractum, Vahl) (Saadah et al., 2018), cengkeh (Eugenia Aromatica), jambu (Jambosa densiflora), kunyit (Curcuma domestica), kayu manis (Cinnamomun burmari), mangga (Magrtifera indica), melinjo (Gnetum gnemon) dan lain sebagainya. Salah satu sumber daya lokal sebagai pewarna alami pada makanan adalah gambir. Gambir berasal dari ekstrak daun tanaman gambir melalui ekstraksi panas dan tekanan.

Gambir merupakan komoditi multimanfaat baik untuk tekstil, kulit, kosmetik, kesehatan dan makanan. Di bidang pangan gambir digunakan sebagai antioksidan dan pengawet (Kamsina and Firdausni, 2018). Sedangkan untuk pewarna, selama ini gambir digunakan sebagai pewarna pada produk tekstil, diantaranya pewarna kain batik (Failisnur et al., 2017) . Penggunaan gambir sebagai pewarna pada produk pangan diragukan karena dikhawatirkan akan menimbulkan rasa sepat pada produk pangan akibat kandungan tanin yang ada dalam gambir tersebut. Dilakukan penelitian pemanfaatan gambir sebagai pewarna pada produk pangan dengan memanfaatkan senyawa tanin dan katekin yang ada pada gambir, dimana senyawa tersebut tidak berasa dan sering menimbulkan rasa manis bila dikunyah dalam waktu yang lama. Pembangkit warna (fixer) diperlukan untuk dapat memberi arah warna yang diinginkan dan warna tersebut stabil. Pada penelitian pembangkit warnanya digunakan asam sitrat, asam askorbat dan kapur sirih.

Penelitian bertujuan untuk melihat karakteristik warna gambir melalui ekstraksi tanin dan katekin dengan menggunakan pembangkit warna, juga mendapatkan pelarut dan pembangkit warna yang optimum untuk mendapatkan pigmen gambir pewarna pangan, intensitas warna dan arah warna dari pewarna gambir untuk pangan.

\section{Metode}

Bahan baku berupa gambir yang diekstrak dari daun gambir, dicuci agar bebas dari kotoran, aquades, alkohol, asam sitrat, asam askorbat, kapur sirih dan zat kimia untuk pengujijan aquades, metanol, larutan 1,1 diphenyl-2-picrylhydrazyl hydrate (DPPH), etanol teknis, katekin pembanding SIGMA.

Peralatan yang digunakan antara lain saringan, sendok pengaduk, peralatan gelas, dan alat-alat untuk pengujian, centrifuse, spektrofotometer UV-Visible, (XRD), spektrofotometer premier color scan SS 6200.

\subsection{Rancangan penelitian}

Penelitian dilakukan dengan metode ekstraksi dan maserasi menggunakan pelarut (air, etanol 25\%, etanol $50 \%$ ) dan pembangkit warna (asam sitrat 3\%, asam askorbat 3\% dan kapur sirih 5\%). Gambir yang digunakan berasal dari ekstrak daun gambir dengan perebusan, ekstraksi, penyaringan, pengendapan sehingga dihasilkan gambir dengan kualitas yang baik bebas dari kotoran. 


\subsection{Pelaksanaan penelitian}

\subsubsection{Penyiapan bahan baku gambir}

Penyiapan bahan baku gambir yang diperoleh dari gambir yang berasal dari Kabupaten Lima Puluh Kota Sumatera Barat. Penelitian dilakukan di Balai Riset dan Standardisasi Industri Padang. Pengujian evaluasi intensitas warna, arah warna dilakukan di Sekolah Tinggi Teknologi Tektil Bandung. Analisis Aktivitas antioksidan di Laboratorium Universitas Andalas sedangkan uji XRD (X-Ray Diffraction) dan FTIR (Fourier Transform Infra Red) di Laboratorium Universitas Negeri Padang.

Persiapan bahan baku gambir yang bebas dari kotoran dan bersih yaitu gambir dilarutkan dengan air panas suhu $70^{\circ} \mathrm{C}$, di aduk dengan saringan 400 mesh selanjutnya maserasi selama 1 x 24 jam sehingga akan terpisah lapisan atas supernatan dan lapisan bawah berupa endapan. Endapan atau gambir bersih dikeringkan sehingga menjadi gambir bubuk. Gambir bubuk yang sudah bersih tersebut digunakan sebagai bahan baku pewarna pangan. Ekstraksi pewarna tanin dari gambir dilakukan dengan menggunakan pelarut yang dikombinasikan dengan pembangkit warna. Pembangkit warna atau fiksasi dilakukan untuk menguatkan warna dan memberikan arah warna sesuai dengan bahan fiksator yang digunakan.

\subsubsection{Proses ekstraksi warna}

Penelitian dilakukan melalui ekstraksi dengan menggunakan pelarut. Pemilihan pelarut polar air dan etanol pada konsentrasi yang berbeda dengan penambahan pembangkit warna akan menghasilkan warna dengan intersitas yang berbeda. Pengambilan ekstrak warna dilakukan dengan sistem ekstraksi maserasi dengan pelarut yang sesuai dengan bahan baku yang digunakan. Bahan baku gambir berupa bubuk yang sudah bersih ditimbang $30 \mathrm{~g}$ dilarutkan dengan pelarut air etanol $600 \mathrm{~mL}$. Diaduk dan dihomogenkan ditambahkan $10 \mathrm{ml}$ pembangkit warna (fiksator) dimaserasi selama 1 x 24 jam. Dilakukan penyaringan dengan kertas saring, larutan hasil saringan di centrifuse dengan kecepatan 10.000 rpm selama 10 menit sehingga didapatkan dua lapisan supernatan dan endapan, larutan supernatan selanjutnya diuapkan pelarutnya dengan vakum putar sehingga didapatkan larutan kental. Ekstrak kental yang diperoleh, lalu dikeringkan. Produk yang sudah dikeringkan dihaluskan. Hasil ekstraksi warna yang dihasilkan dilakukan pengujian intensitas warna, rendemen, dan karakteristik warna yang dihasilkan yang digunakan sebagai pewarna pangan.

\subsection{Pengujian dan analisis}

\subsubsection{Tampilan fisiologis pewarna gambir}

Pengamatan warna gambir yang didapatkan pada proses ekstraksi mulai dari ekstraksi dengan penggunaan pelarut penambahan pembangkit pewarna. Persentase rendemen pewarna gambir yang dihasilkan dari pemakaian bahan baku gambir, tekstur dan penampakan warna pangan dari gambir.

\subsubsection{Intensitas warna, ketuaan warna dan nilai beda warna.}

Pengujian intensitas warna dilakukan dengan metode Spektrofotometer Cahaya Tampak "Premiere Colorscan" SS 6200. Nilai kuantitatif untuk intensitas warna diperoleh dengan cara mengukur nilai persen reflektansi (\%R) pada panjang gelombang yang sama lalu dikonversikan nilai K/S dengan bantuan tabel K/S sesuai dengan teori Kubelka-Munk.

$\mathrm{K} / \mathrm{S}=\frac{(1-\mathrm{R})^{2}}{2 \mathrm{R}}=\mathrm{aC}$

Dimana $\mathrm{K}$ adalah koefisien absorpsi (cahaya yang diserap), $\mathrm{S}$ adalah koefisien cahaya yang disebarkan, $\mathrm{C}$ merupakan nilai hue dan $\mathrm{R}$ adalah nilai persen reflektansi pada panjang gelombang tertentu (max) (Mirjalili and Karimi, 2013)

\subsubsection{Aktivitas antioksidan metode DPPH}

Metode yang dilakukan untuk pengujian aktivitas antioksidan pada penelitian melalui metode DPPH (2,2-diphenyl-1-picrylhydrazyl). Kapasitas penangkapan radikal bebas DPPH ditentukan penentuan nilai $\mathrm{IC}_{50}$ yaitu sampel sebanyak 0,2 $\mathrm{ml}$ ditambah $3,8 \mathrm{ml}$ larutan DPPH 0,1 mM, divortek 1 menit, dan diinkubasi pada suhu kamar dan ruang gelap selama 30 menit. Jika semua elektron DPPH berpasangan dengan elektron pada sampel ekstrak maka akan terjadi perubahan warna sampel dimulai dari ungu tua hingga kuning terang. Absorbansi ditera pada $\lambda 517 \mathrm{~nm}$. Blanko (kontrol) dengan menggunakan etanol sebagai pengganti sampel. Daya tangkap radikal bebas dinyatakan dalam persen $(\%) \mathrm{RSA}=$ merupakan $\%$ pemucatan $\mathrm{DPPH}$, didapatkan nilai $\mathrm{IC}_{50}$

$\% \operatorname{RSA}=\frac{\mathrm{Ac}-\mathrm{A}}{\mathrm{Ac}} \times 100 \%$

Keterangan:

Ac $=$ nilai absorbansi kontrol

$\mathrm{A}=$ nilai absorbansi sampel

\subsubsection{Analisis kurva FTIR ( Fourier Transform Infra Red)}

Sampel ditempatkan pada plat kristal, analisis dibuat pada frekuensi 4000-650cm-1. Setiap selesai pengukuran plat dibersihkan dengan hexane sebanyak dua kali dan aseton sampai tidak ada sampel minyak yang tertinggal lalu keringkan dengan menggunakan tissue. Setelah proses scan selesai, spektrum udara diambil. Semua pengukuran diulang sebanyak tiga kali (Hasyimet al.,2010). Spektrum inframerah yang diperoleh kemudian diplot sebagai intensitas fungsi energi, panjang gelombang $(\mathrm{m})$ atau bilangan gelombang $(\mathrm{cm}-$ 1) (Sulistyani, 2018) 


\subsubsection{Derajat kristalinitas dengan X-Ray Diffaction (XRD)}

Metode analisis berupa metode serbuk, bahan sampel pada metode ini dibuat berbentuk serbuk, sehingga terdiri banyak kristal yang sangat kecil dan orientasi sampai tidak perlu diatur lagi kerena semua orientasi bidang telah ada dalam sampel. Metode lebih cepat dan lebih sederhana dibandingkan dengan metode kristal tunggal. Metode serbuk ini dapat digunakan untuk menganalisis bahan apa yang terkandung di dalam suatu sampel juga dapat ditentukan secara kwantitatif. Hukum dasar dalam difraksi sinar X mengacu pada Hukum Bragg.

\section{Hasil dan pembahasan}

\subsection{Profil pewarna pangan gambir}

Ekstraksi gambir dengan menggunakan pelarut etanol $50 \%$ memberikan arah warna yang kuat dibandingkan dengan menggunakan pelarut etanol $25 \%$ dan air. Etanol merupakan pelarut polar protik yaitu memberikan ion $\mathrm{OH}^{-}$sehingga mudah berintegrasi dengan gugus fungsional yang polar pada tanin. Konsentrasi tanin maksimum diperoleh dari ekstraksi dengan menggunakan pelarut polar protik etanol dan metanol karena mudah berintegrasi dengan gugus fungsional yang polar pada tanin. (Marnoto et al., 2012). Pelarut yang digunakan seperti pelarut etanol merupakan pelarut food grade sehingga aman digunakan.

Pengamatan terhadap $\mathrm{pH}$, rendemen, warna yang dihasilkan setelah penambahan pembangkit warna pada ekstrak gambir seperti pada Tabel 1. Hasil pengamatan secara fisiologis pengaruh penambahan pembangkit warna dengan menggunakan pelarut etanol 50\% menunjukkan bahwa $\mathrm{pH}$ larutan warna gambir memberikan warna yang berbeda tergantung dari pembangkit warna yang digunakan. Pembangkit warna asam sitrat 3\% dengan $\mathrm{pH}$ 4,3 memberikan warna merah kekuningan dan lebih terang dibandingkan dengan perlakuan asam askorbat dan kapur sirih. Ekstraksi warna gambir dengan pembangkit warna kapur sirih menghasilkan warna merah kecoklatan pada larutan warna setelah maserasi.

Tabel 1

Hasil pengamatan larutan warna pangan gambir dengan menggunakan pembangkit warna

\begin{tabular}{llll}
\hline \multirow{2}{*}{ Perlakuan } & \multicolumn{2}{l}{ Pengamatan } & Rendeman (\%) \\
\cline { 2 - 4 } Asam sitrat 3\% & $\mathrm{pH}$ & Warna & $\begin{array}{l}\text { Warna merah } \\
\text { kekuningan dengan } \\
\text { endapan kecoklatan }\end{array}$ \\
Asam askorbat 3\% & 4,6 & $\begin{array}{l}\text { Warna kemerahan } \\
\text { dengan endapan } \\
\text { coklat }\end{array}$ & 9,33 \\
Kapur sirih 3\% & 8,4 & $\begin{array}{l}\text { Warna merah tua } \\
\text { dengan endapan } \\
\text { coklat kemerahan }\end{array}$ & 11,67 \\
\hline
\end{tabular}

Rendemen warna yang dihasilkan pada perlakuan penambahan pembangkit warna dengan pelarut etanol $25 \%$ berada sekitar 9,33\%-11,67\% (b/b dari gambir bubuk). Pengadukan dan suhu yang tepat dapat mengekstrak warna lebih tinggi. Ekstraksi warna dengan suhu lebih dari $70^{\circ} \mathrm{C}$ pada kulit manggis akan menyebabkan penurunan intensitas warna (Aji and Ferani, 2013). Rendemen tertinggi pada pembangkit warna kapur sirih $11,67 \%$. Ekstraksi pewarna gambir dipengaruhi oleh jenis pelarut, konsentrasi pelarut, $\mathrm{pH}$, ukuran partikel dan sifat dari bahan baku (Aji and Ferani, 2013).

Rendemen warna pada asam sitrat 9,33\% lebih rendah dari perlakuan asam askorbat 9,68\%. Asam sitrat mempunyai sumber karbon utama yaitu glukosa. Asam sitrat dapat mengikat ion ion logam sehingga digunakan sebagai pengawet dan penghilang kesadahan air. Pada proses pengolahan makanan asam sitrat dapat berfungsi sebagai pengawet sebagai pengawet, pengemulsi, pengatur $\mathrm{pH}$ dan antioksidan (Fajarwati et al., 2017).

\subsection{Intensitas dan nilai beda warna}

Hasil analisis terhadap pewarna gambir pangan dengan perlakuan jenis pelarut yang digunakan dan pembangkit warna asam asetat, asam sitrat dan kapur sirih. Pengamatan intensitas warna seperti pada Tabel 2. Nilai panjang gelombang maksimum berada pada 400 $\mathrm{nm}$ pada semua jenis pembangkit warna, dimana nilai panjang gelombang merupakan data spesifik yang memberikan informasi warna. Panjang gelombang ini merupakan indikasi dari cahaya tampak yang pada umumya dimiliki oleh pewarna alam, seperti panjang gelombang antosianin pada ekstrak ubi jalar ungu pada $520 \mathrm{~nm}-700 \mathrm{~nm}$ (Husna et al., 2013). 
Tabel 2.

Nilai intensitas dan nilai beda warna pewarna pangan dari gambir

\begin{tabular}{lcllll}
\hline Jenis Mordan & $\lambda(\mathrm{nm})$ & $\mathrm{L}^{*}$ & $\mathrm{~K} / \mathrm{S}$ & $\mathrm{a}^{*}$ & $\mathrm{~b}^{*}$ \\
\hline $\begin{array}{l}\text { Asam sitrat } \\
\text { 3\% }\end{array}$ & 400 & 42,38 & 0,81 & 5,36 & 21,12 \\
$\begin{array}{l}\text { Asam askorbat } \\
\text { 3\% }\end{array}$ & 400 & 79,60 & 1,15 & 6,50 & 23,99 \\
$\begin{array}{l}\text { Kapur sirih } \\
5 \%\end{array}$ & 400 & 81,47 & 4,09 & 6,88 & 8,17 \\
\hline
\end{tabular}

Keterangan: L* kecerahan (lightness), a* kemerahan (redness) dan $\mathrm{b}^{*}$ kekuningan (yellowness)

Pengamatan intensitas kecerahan warna dapat dilihat dari nilai L (lighness). Perlakuan pembangkit warna memberikan pengaruh pada L tingkat kecerahan warna. Asam sitrat dengan $\mathrm{L}$ terendah 42,38. Nilai $\mathrm{L}$ menunjukkan bahwa semakin tinggi nilai L maka makin cerah warna yang terlihat, begitu sebaliknya makin kecil nilai L makin suram warna. Hasil analisis pengaruh jenis pembangkit warna pada pembuatan warna gambir memberikan karakteristik warna yang berbeda. Pewarna gambir dengan pembangkit warna kapur sirih dengan nilai $\mathrm{L}$ tertinggi sebesar 81,47 diikuti oleh asam sitrat 79,60 dan asam askorbat 42,38.

Ketuaan warna dapat dilihat dari nilai K/S. K sebagai koefisien penyerapan cahaya dan $\mathrm{S}$ koefisien penghamburan cahaya. Nilai ketuaan warna yang tinggi ditunjukkan dengan nilai K/S yang tinggi. Perlakuan dengan pembangkit warna kapur sirih dengan nilai K/S tertinggi 4,09 dibandingkan dengan asam sitrat dan perlakuan pembangkit warna asam askorbat. Hal ini menunjukkan bahwa pada suasana basa akan memberikan warna yang lebih tua dengan nilai K/S tinggi dibandingkan dengan pembangkit warna pada $\mathrm{pH}$ asam. (asam sitrat, asam berzoat). Gambir mengandung tanin yang dapat digunakan sebagai pigmen warna. Pigmen tanin dengan pembangkit warna kapur sirih memberikan ketuaan warna tertinggi, sedangkan asam askorbat ketuaan warna lebih tinggi dari asam sitrat. Nilai K/S yang tinggi juga menunjukkan partikel warna yang lebih banyak sehingga cahaya yang terserap lebih besar dan warna yang diberikan semakin kuat dan tua.

Nilai a (redness) merupakan arah warna campuran merah hijau. Nilai a+ untuk warna merah dan a- warna hijau. Nilai a+ berkisar 0-60. Hasil analisis menunjukkan perlakuan pembangkit warna memberikan hasil yang berbeda untuk nilai a (redness). Nilai a tertinggi pada perlakuan kapur sirih 6,88 dengan warna kemerahan dibanding dengan asam askorbat dan asam sitrat. Nilai a yang rendah menunjukkan warna yang tidak kemerahan seperti pada perlakuan asam sitrat dan asam askorbat.

Nilai b (yellowness) merupakan arah warna campuran kuning biru dimana $b+$ untuk warna kuning dan b- untuk biru. Nilai b pada asam askorbat tertinggi 23,99 dibanding asam sitrat 21,12 dan kapur sirih 8,17. Pada Tabel 2 menunjukkan nilai a (redness) dan nilai b (yellowness) merupakan arah warna yang dihasilkan.

Karakteristik warna pada perlakuan ini menunjukkan kecendrungan warna coklat. Tipe warna seperti ini menginterpresikan data warna dari data koordinat ruang warna. Karakteristik warna terlihat dari perbedaan nilai panjang gelombang maksimum dan nilai (a dan b) yang menginterpretasikan koordinat ruang warna. Koordinat warna berada pada koordinat a positif (arah warna merah) dan $b$ positif (arah warna kuning). Pembangkit warna asam sitrat dan asam askorbat memberikan arah warna dengan ratio yang hampir sama yaitu warna dengan $b$ positif (kuning) dan a positif (merah) lebih rendah. Ratio nilai a dan b pada perlakuan asam asetat dan sitrat hampir sama. Sedangkan perlakuan pembangkit warna kapur sirih berbeda jauh dengan perlakuan lainnya dimana ratio nilai a dan b lebih tinggi (cenderung merah). Hal ini menunjukkan bahwa kapur sirih memiliki kejenuhan warna lebih kecil tapi arah warna lebih tegas mengarah warna merah dengan nilai a positif tertinggi yaitu 6.88 .

\subsection{Aktivitas antioksidan}

Hasil analisis aktivitas antioksidan dengan metode DPPH pada pewarna dari gambir dengan menggunakan pembangkit warna (asam sitrat, asam askorbat dan kapur sirih) menunjukkan hasil yang berbeda dengan nilai $\mathrm{IC}_{50}$ lebih tinggi dari standar vitamin $\mathrm{C}(4,45 \mathrm{ppm})$ seperti pada Tabel 3.

Tabel 3

Aktivitas antioksidan gambir, pewarna gambir dan vitamin C menggunakan metode DPPH.

\begin{tabular}{ll}
\hline Perlakuan & $\begin{array}{l}\text { Antioksidan } \mathrm{IC}_{50} \\
\text { DPPH }\end{array}$ \\
\hline Gambir bubuk & $6,67 \mathrm{ppm}$ \\
Gambir dengan asam sitrat & $6,45 \mathrm{ppm}$ \\
Gambir dengan asam askorbat & $6,25 \mathrm{ppm}$ \\
Gambir dengan kapur sirih & $7,84 \mathrm{ppm}$ \\
Standar Vitamin C & $4,45 \mathrm{ppm}$ \\
\hline
\end{tabular}

Pada pengujian aktivitas antioksidan metode DPPH, radikal menjadi stabil karena mendonorkan atom hidrogen (Firdausni et al., 2011). Pewarna gambir selain sebagai pewarna juga sebagai antioksidan. Aktiivitas antioksidan menunjukkan kekuatan antioksidasi sinergi berbagai komponen antioksidan. Gambir dapat digunakan sebagai aktioksidan pada pengolahan pangan. Aktivitas antioksidan gambir sebagai bahan baku mempunyai nilai $\mathrm{IC}_{50} 6.67 \mathrm{ppm}$ lebih tinggi dari standar vitamin $\mathrm{C}$ (4,45 ppm). Hal ini menyatakan semakin kecil nilai $\mathrm{IC}_{50}$ maka semakin tinggi aktivitas antioksidan (Widyastuti et al., 2016). Penggunaan senyawa antioksidan semakin meluas dalam menghambat penyakit degeneratif seperti penyakit jantung, kanker dan penuaan. Hal ini berkaitan dengan kemampuan antioksidan untuk bekerja sebagai inhibitor (penghambat) reaksi oksidasi oleh radikal bebas (Hardisman, 2010). Pewarna gambir dengan perlakuan pembangkit asam sitrat dengan IC 50 lebih kecil dari gambir sebagai bahan baku, sedangkan gambir dengan kapur sirih mempunyai IC 50 lebih tinggi dari gambir sebagai bahan baku. Pewarna gambir dengan pembangkit warna asam sitrat dan askorbat mempunyai aktivitas antioksidan lebih tinggi dari gambir sebagai bahan baku. Semakin kecil nilai IC 50 maka semakin tinggi aktivitas antioksidan. Salah satu yang 
mempengaruhi aktivitas antioksidan diantaranya suhu pada waktu proses ekstraksi (Hartiati et al., 2017)

\subsection{Analisis spektrum FTIR.}

Spektrum FTIR perlakuan pembangkit warna asam sitrat, asam askorbat dan kapur sirih seperti terlihat pada Gambar 1. Analisis FTIR (Fourier Transform Infared Spectroscopy) digunakan untuk mendeteksi adanya suatu gugus fungsional yang terkandung pada sampel dengan teknik yang cepat, sederhana, dan non destruktif seluruh sifat kimia.

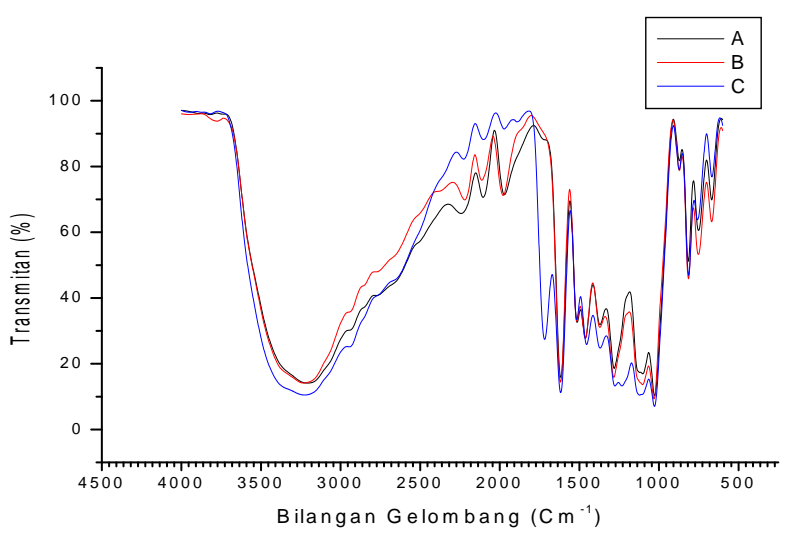

Gambar 1. Spektrum FTIR pewarna gambir dengan pembangkit warna $\mathrm{A}$ (asam sitrat), B (asam askorbat), dan C (kapur sirih)

Profil spektrum FTIR pewarna gambir memberikan pola seperti pada Gambar 1. Intensitas serapan maksimum pada bilangan gelombang $1.280 \mathrm{~cm}^{-1}$ dan $3.207 \mathrm{~cm}^{-1}$ untuk pembangkit warna asam sitrat, 1.031 $\mathrm{cm}^{-1}$ dan $3.232 \mathrm{~cm}^{-1}$ untuk asam askorbat dan 1.233 $\mathrm{cm}^{-1}$ dan $3.226 \mathrm{~cm}^{-1}$ untuk pembangkit warna kapur sirih. Puncak gelombang utama pada panjang gelombang $3.207 \mathrm{~cm}^{-1}$ untuk asam sitrat, $3.232 \mathrm{~cm}^{-1}$ untuk asam askorbat dan $3.226 \mathrm{~cm}^{-1}$ untuk kapur sirih. Hal ini berhubungan dengan gugus fungsional hidroksil $\mathrm{O}-\mathrm{H}$ fenolik. Puncak yang tajam ditemukan pada panjang gelombang $1.280 \mathrm{~cm}^{-1}$ untuk asam sitrat $1.031 \mathrm{~cm}^{-1}$ asam askorbat dan $1.233 \mathrm{~cm}^{-1}$ pada kapur sirih, ditemukan kelompok dengan gugus fungsional karboksil C-O dan C-N. Adanya puncak gelombang kecil pada $1.619 \mathrm{~cm}^{-1}$ - $1.971 \mathrm{~cm}^{-1}$ merupakan mode peregangan $\mathrm{C}-\mathrm{O}$ dan $\mathrm{C}$ $\mathrm{H}$ dan C-C. Gugus fungsi tersebut berperan dalam menghasilkan warna yang merupakan gugus fungsi hidroksil.

Dilihat dari pola FTIR yang terbentuk, menunjukkan pola yang sama dengan pewarna alam dari ekstrak limbah kulit jengkol (Archidendron jiringa), dimana pita serapan kuat dikaitkan dengan mode vibrasi peregangan dari ikatan $\mathrm{O}-\mathrm{H}$ dalam permukaan gugus hidroksil atau molekul air teradsorpsi (Failisnur et al., 2018)

\subsection{X-Ray Diffraction (XRD)}

Hasil analisis XRD pada warna alami gambir Tabel 4 menunjukkan kandungan yang berbeda. Perlakuan asam askorbat dan asam sitrat dengan pola yang hampir sama (Gambar 2 dan 3). Puncak yang dihasilkan menunjukkan senyawa yang dikandung oleh Puncak atau peak yang dihasilkan menunjukkan senyawa yang terdapat pada sampel uji. Pembangkit warna berfungsi untuk dapat meningkatkan kestabilan warna, melalui ekstraksi dengan menggunakan pelarut dan penambahan pembangkit warna akan mendapatkan warna dengan intensitas yang baik. Puncak atau peak yang dihasilkan menunjukkan senyawa yang terdapat pada sampel uji. Ekstrak pewarna dengan asam sitrat dan benzoat mengandung fenol, katekin, dan pirokatekol.

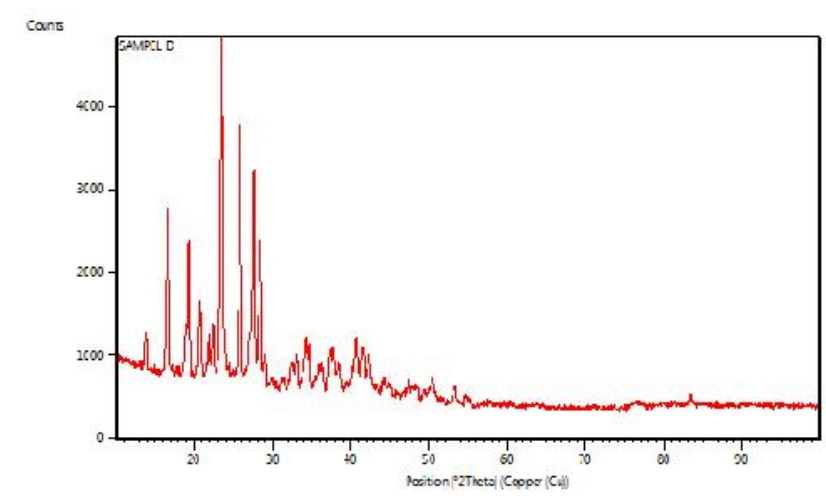

Gambar 2. Pola XRD pewarna gambir dengan pembangkit warna asam sitrat.

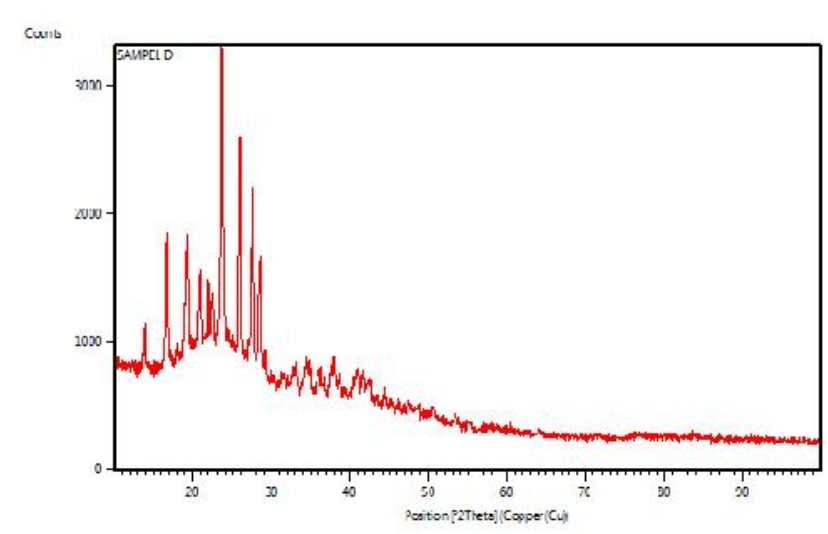

Gambar 3. Pola XRD pewarna gambir dengan pembangkit warna asam askorbat.

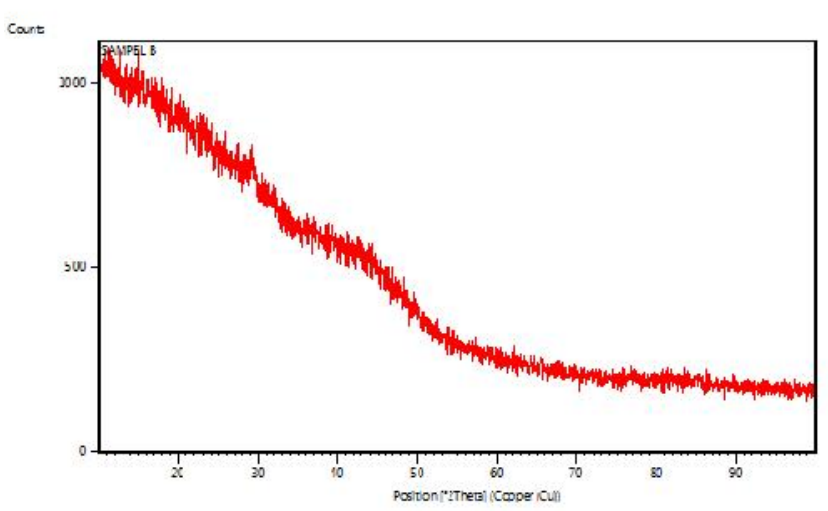

Gambar 4. Pola XRD pewarna gambir dengan pembangkit warna kapur sirih

Pembangkit warna kapur sirih tidak mendapatkan puncak yang jelas karena beberapa senyawa dalam bentuk amorf yang memiliki struktur tidak teratur 
(Gambar 4). Pembangkit warna berfungsi untuk dapat meningkatkan kestabilan warna, melalui ekstraksi dengan menggunakan pelarut dan penambahan pembangkit warna akan mendapatkan warna dengan intensitas yang baik.

Tabel 4

Persentase kandungan senyawa pada pewarna pangan gambir dengan X-ray Diffraction (XRD)

\begin{tabular}{lllll}
\hline \multirow{2}{*}{ Senyawa } & Rumus kimia & \multicolumn{2}{l}{ Pembangkit warna } & \\
\cline { 3 - 4 } & & Asam askorbat & Asam sitrat & Kapur sirih \\
\hline Acetic (\%) & $\mathrm{C}_{2} \mathrm{H}_{4} \mathrm{O}_{2}$ & 0.206 & 0.183 & 0.000 \\
Citric (\%) & $\mathrm{C}_{6} \mathrm{H}_{8} \mathrm{O}_{7}$ & 0.137 & 0.193 & 0.000 \\
Ascorbit acid (\%) & $\mathrm{C}_{6} \mathrm{H}_{8} \mathrm{O}_{6}$ & 0.171 & 0.133 & 0.000 \\
Phenol (\%) & $\mathrm{C}_{6} \mathrm{H}_{6} \mathrm{O}$ & 0.092 & 0.955 & 0.000 \\
Catechin (\%) & $\mathrm{C}_{15} \mathrm{H}_{14} \mathrm{O}_{6}$ & 0.031 & 1.725 & 0.000 \\
d-Catechin-á- (\%) & $\mathrm{H}_{14} \mathrm{O}_{6} \cdot \mathrm{H}_{2} \mathrm{O}$ & 0.388 & 0.569 & 0.000 \\
Pyrocatechol (\%) & $\mathrm{C}_{6} \mathrm{H}_{6} \mathrm{O}_{2}$ & 0.401 & 0.458 & 5.362 \\
Calcium Hydroxide $(\%)$ & $\mathrm{Ca}(\mathrm{OH})_{2}$ & 0.000 & 0.000 & 1.963 \\
\hline
\end{tabular}

\section{Kesimpulan}

Hasil penelitian dapat disimpulkan bahwa perlakuan jenis pelarut dan pembangkit warna berpengaruh terhadap intensitas dan arah warna gambir yang dihasilkan. Pemakaian pelarut etanol $25 \%$ dan asam askorbat 3\% menghasilkan kecerahan warna L 79,60 lebih tinggi dari perlakuan dengan asam sitrat $3 \%$ namun rendah dari pembangkit warna kapur sirih. Intensitas warna (K/S) tertinggi pada kapur sirih.4,09 dengan warna kemerahan ( $a^{*}$ 6.5). Arah warna dari penambahan asam sitrat lebih kekuningan, begitu juga dengan asam askorbat. Aktivitas antioksidan menggunakan asam askorbat dengan $\mathrm{IC}_{50} 6,25 \mathrm{ppm}$ dengan aktivitas antioksidan lebih kecil dari Vitamin C (4,45 ppm). Hasil analisis gugus fungsional FTIR menghasilkan pola dengan puncak yang berbeda, gugus fungsional warna gambir yang berperan dalam penguatan zat warna terutama gugus fungsi hidroksil dan karboksil.

\section{Ucapan terima kasih}

Terima kasih kepada Balai Riset dan Standardisasi Industri Padang yang telah membantu pendanaan sehingga penelitian berjalan dengan lancar. Terima kasih juga disampaikan kepada Elya Rovina, Titi Putri Ningsih yang telah membantu kelancaran penelitian ini.

\section{Daftar pustaka}

Aji, A., Ferani, A.S., 2013. Pembuatan pewarna makanan dari kulit buah manggis dengan proses ektraksi. Teknol. Kim. Unimal 2, 1-15.

Failisnur, F., Sofyan, S., 2014. Sifat tahan luntur dan intensitas warna kain sutera dengan pewarna alam gambir (Uncaria gambir Roxb) pada kondisi pencelupan dan jenis fiksator yang berbeda. J. Litbang Ind. 4, 1-8. https://doi.org/10.24960/ jli.v4i1.634.1-8

Failisnur, F., Sofyan, S., Hermianti, W., 2017. Pemanfaatan limbah cair pengempaan gambir untuk pewarnaan kain batik. J. Litbang Ind. 7, 19-28. https://doi.org/10.24960/jli.v7i1.2695.19-28
Failisnur, F., Sofyan, S., Silfia, S., Sy, S., Ardinal, A., 2018. Biomordan gambir pada pewarnaan kain viskos menggunakan ekstrak pewarna dari limbah kulit jengkol (Archidendron jiringa) . J. Litbang Ind. 8, 77-82. https://doi.org/10.24960/jli.v8i2 .4324.7782

Fajarwati, N.H., Parnanto, N.H.R., Manuhara, G.J., 2017. Pengaruh konsentrasi asam sitrat dan suhu pengeringan terhadap karakteristik fisik, kimia dan sensoris manisan kering labu siam (Sechium edule Sw.) Dengan pemanfaatan pewarna alami dari ekstrak rosela ungu (Hibiscus sabdariffa L.). J. Teknol. Has. Pertan. 10, 50-66. https://doi.org/10. 20961/JTHP.V10I1.17494

Firdausni, F., Diza, Y.H., Failisnur, F., 2011. Potensi pigmen cassiavera pada minuman jahe instan sebagai minuman fungsional. J. Litbang Ind. 1, 15-21. https://doi.org/http://dx.doi.org/10.24960/ jli.v1i1.590.15-21

Handayani. P A, Rahmawati Asri, 2012. Pemanfaatan kulit buah naga (dragon fruit) sebagai pewarna alami makanan pengganti pewarna sintetis. J. Bahan Alam Terbarukan 1, 19-24.

Hardisman, 2010. Pencegahan penyakit degeneratif dan pengaturan makanan. Maj. Kedokt. Andalas 34, 168 172.

Hartiati, A., Mulyani, S., Pusparini, N.M.D., 2017. Pengaruh preparasi bahan baku rosella dan waktu pemasakan terhadap aktivitas antioksidan sirup bunga rosella (Hibiscus sabdariffa L.). Agrotekno 15, 20-24. https://doi.org/10.3303/CET1756095

Husna, N., Novita, M., Rohaya, S., 2013. Kandungan antosianin dan aktivitas antioksidan ubi jalar ungu segar dan produk olahannya. J. Agritech Fak. Teknol. Pertan. UGM 33, 296-302. https://doi.org/ 10.22146/agritech.9551

Kamsina, K., Firdausni, F., 2018. Pengaruh penggunaan ekstrak gambir sebagai antimikroba terhadap mutu dan ketahanan simpan cake bengkuang (Pachyrhizus erosus). J. Litbang Ind. 8, 111-117. https://doi.org/10.24960/JLI.V8I2.4329.111-117

Li, J., Zhang, L., Liu, Y., 2013. Optimization of extraction of natural pigment from purple sweet potato by response surface methodology and its 
stability. J. Chem. 1-5. https://doi.org/10.1155/ 2013/590512

Marnoto, T., Haryono, G., Gustinah, D., Putra, F.A., 2012. Ekstraksi tannin sebagai bahan pewarna alami dari tanaman putrimalu (Mimosa Pudica) Menggunakan Pelarut Organik. REAKTOR 14. https://doi.org/10.14710/reaktor.14.1.39-45

Mirjalili, M., Karimi, L., 2013. Extraction and characterization of natural dye from green walnut shells and its use in dyeing polyamide: Focus on antibacterial properties. J. Chem. 1-10. https://doi. org/10.1155/2013/375352

Saadah, M., Nurdiana, N., Wahyudiati, D., 2018. Uji kadar zat warna ( $\beta$-karoten) pada cabe merah (Capsicum annum. Linn) sebagai pewarna alami. Biota 9, 86-95. https://doi.org/10.20414/jb.v9i1.40

Shahid, M., Shahid-Ul-Islam, Mohammad, F., 2013. Recent advancements in natural dye applications: A review. J. Clean. Prod. https://doi.org/10. 1016/j.jclepro.2013.03.031

Sulistyani, M., 2018. Spektroskopi Fourier transform infra red metode reflektansi (Atr-Ftir) pada optimasi pengukuran spektrum vibrasi vitamin C. J. TEMAPELA 1, 39-43. https://doi.org/ 10.25077/temapela.1.2.39-43.2018

Suter, K., 2013. Pangan fungsional dan prospek pengembangannya, in: Teknologi Pangan. Seminar Sehari dengan tema "Seminar Sehari dengan tema "Pentingnya Makanan Alamiah (Natural Food) Untuk Kesehatan Jangka Panjang”, pp. 1-17.

Widyastuti, W., Kusuma, A.E., Nurlaili, N., Sukmawati, F., 2016. Aktivitas antioksidan dan tabir surya ekstrak etanol daun stroberi (Fragaria $\mathrm{x}$ ananassa A.N. Duchesne). J. Sains Farm. Klin. 3, 19-24. https://doi.org/10.29208/jsfk.2016.3.1.92 